\title{
The Growth of Visual Arts as a Motor for Empowerment in Nigeria
}

\author{
Bojor Enamhe (Ph.D)
}

\author{
Umana Nnochiri \\ Department of Visual Arts and Technology, \\ Cross River University of Technology, Calabar, Cross River State, Nigeria \\ Email: blossomenamhe@yahoo.com
}

Doi:10.5901/ajis.2013.v2n11p26

\begin{abstract}
This paper will focus on the development of Visual Arts in Nigeria from the primary, secondary and tertiary institutions for creation of awareness of the subject. It argues that when this is done, insight into the situation can be revealed and promoted for improved participation in art activities. Art has been relegated to the background for too long now due to misunderstanding and misconceptions of what art entails and the benefits of the subject. It is time to forcefully plant the subject as a compulsory one through such academic meetings. Visual Arts can lead to poverty reduction if properly applied and harnessed due to its creative and skill related nature. From this study, it can be deduced that graduates of art can make a living from art, and also be able to employ labour and art studios can grow beyond subsistence level of production to larger ones thereby reducing unemployment in the country. The main contribution of the paper is an emphasis on the need to introduce visual arts in schools and Colleges to increase the number of persons involved in art.
\end{abstract}

\section{Introduction}

The importance of Visual Arts to any educational system or society cannot be overemphasized. For decades now, this subject has suffered lack of recognition and low participation. This kind of discussion; is not new, conferences, workshops, and seminars have been organized with the aim of making things right. Efforts made by the Federal Government on reforms in all sectors of the economy have proved abortive. The Federal Government Educational Policy, to include Fine Arts as a subject in the school curriculum has failed, it may be, due to lack of teachers in the primary and secondary schools. This brings us to the sorry state of Visual Arts. In the book, "understanding Art in General Education" written by an art Scholar, Uzoagba (2002) with foreword written by another scholar Professor Von Stoker, who stated that, "this profession has been extremely neglected in Nigeria and throughout West Africa where its importance is still not recognized". A lot has been said about the poor state of the arts but this paper steers an analytical debate, which supposedly has something to contribute. This is because no view is completely useless or unreasonable.

Information can be changed or modified in the continuous search to overcoming the challenge. What we are then saying according to Prof Von Stocker (2002) states that, "this book by young Nigerian art educator rises as a cry against the big forest of ignorance misunderstanding and neglect, planted and nourished by the superficiality of education in West Africa, intellectuals now holding responsible positions in government administration, education and cultural affairs. The lack of a broad general education and the "too-early" specialization of West African intellectuals certainly account for the decline of the art of West Africa and the inability to see and over-come the threat of the machine age. There is a gap created in the visual arts that seeks redress. Visual arts has been poorly addressed and so much left to change. People ought to realize that art is the crafted representation by man which requires the application of skill to refine into valuable possession. "Visual Arts as a subject sparks creativities in diverse ways, a well trained visual artist explores and experiment constantly in line with the changing society. When visual art is re-invigorated, there will be employment opportunities and expansion of labour market. The experimental nature of the discipline has the capacity to continue to break new grounds for more employment opportunities culminated into self-reliance (Dashen and Nyohom, 2012) Visual Arts, train students for productivity this comes from the philosophical notion that real knowledge is experimental.

This is why the tertiary institutions cannot produce the needed manpower in Visual Arts (see Ajibade, Enamhe and Oloidi, 2011) when the foundation is faulty, the house suffers. Most graduates from schools are jobless and so are redundant, some have joined bad groups to commit crime and other multifarious activities. It is high time for people to begin to develop themselves by studying courses that will alleviate this problem since the public sector is diminishing in 
job creation. Also it is worth mentioning that some careers are becoming economic wastelands in skills needed for application of techniques in solving problems and creating objects. Using literature as support, this study focuses on reintroducing visual arts in all levels of education in Nigeria.

\section{What is Growth in Visual Art?}

Growth is inevitable in all human endeavours. A child seeks to grow to adulthood, every business aspires for growth, in the school system, pupils/students study to grow from one level to another, in jobs; workers work in expectation of growth (promotion) significant changes in the realm of Visual Arts as a career, calls for growth or a developmental process which will enhance a better participation in the field. This process is maturation, which means either a qualitative or quantitative achievement, creating a change from one stage to another. The place of visual arts in Nigeria has been highly neglected. Uzoagba (2002) decried on this deplorable situation that, "although the teaching of art (drawing and painting) in schools and colleges has been generally accepted, art is not always found in most schools and colleges". It is assumed that, because of the dis-interest shown by schools, more and more students drop the subject as they advance, Uzoagba (2002), Enamhe and Echeta (2008) and Dashen and Nyohom (2012).

"The teaching of Fine/Applied Arts, as a subject is at the bottom of the list of priorities, the turn over of art teachers is not slow but also too small to cope with the manpower needs of the $21^{\text {st }}$ century" (Talabi, 1979). According to Enamhe and Echeta (2008) this decline of art culture in schools is steadily eroding the subject in primary and secondary schools. Ajibade and Lawson (2003) recorded data of students in some secondary schools in Calabar metropolis, Cross River State, Nigeria between 1998 - 2002, as, 16 students out of 219 secondary schools offered Fine Arts. In another study by Ajibade, Enamhe and Oloidi, (2011) reported that only a few secondary schools in Cross River State offered arts. This greatly affects admission into the university or tertiary institution to study Visual Arts.

An artist, Echeta (2011) reports that, "perhaps, one of the few disciplines which many educated people seem to 'know' no matter their areas of specialization, is Art engaging such in discussions at art exhibition grounds or in art studios suggest otherwise. This continuing residency of Visual Arts illiteracy along the corridor of high profile educationist and sometime policy makers has become a worrisome scenario". This scholar argues that the figure is partially because Art as Educational resource fails to be accorded its rightful place because of acts of omission or commission at various levels. It is because of these critical issues raised that this study examined ways to redeem Visual Arts from its poor state to a higher level, which is growth, to enable employment and self-reliance.

\section{Visual Arts Characterized}

Frank Ugiomoh (2012) reviewed various meanings, definitions and discussions on art, but for this study, a few of them with similar focus shall be discussed. "The word Art sits at the foundation of all human activities and achievements" considering the Roman translation of Ars, which means skill, Ugiomoh opines that, also synonyms of ability, cleverness, dexterity etc. Quoting Marxist Scholar Ernst Fisher, Ugiomoh (2012) stated that, "the earliest hominoid created the first work of art by responding to the inadequacies of objects nature adapted for specific objectives. For example, a stick without a stub to harvest a fruit will demand that it be properly adapted and filled with such device to serve the purpose of harvest and/or other functions that might have been necessary. Restooling or reinventing, which the stick has undergone automatically converts it to an artifact; a product of culture" such activities undertaken, by man need skill, as art. That, which was created during the mediaeval period, reveals art as skill.

Modern art, since its formal introduction in 1927 in the curriculum to be taught in schools, has stood out as a discipline that promotes power of thinking and imagination; and to fully develop the instinctive tendency in the child (Bashen and Nyohom, 2012).

Art taught in Kindergaten and primary schools is very different from that taught in the secondary school level. Children love to paint and draw, they participate in such activities before they learn how to read and write. In order words, teaching art at this level is not a difficult task. The subject is easily understood, Uzoagba opines that, "art activities can be easily assimilated to play activities, so occupy most of the timetable in children classes. So with this, art can be introduced to children in the primary school. Dashen and Nyohom (2012) stated that, "children are imaginative and experimental with any material they handle. It is perhaps in realization of inherent creative potentials in children that makes Osagie (1995:40) to state that is equipping citizens to meet the current developmental challenges is to introduce them early enough to areas of learning that stimulate creativity". This is because children at this level play freely with 
materials and they express their impulses spontaneously. The primary school syllabus according to Uzoagba (2002) reads as follows:

a) Pattern building with objects, lines shapes and colours

b) Finger prints.

c) Paper teaching, folding, collage and mosaic.

d) Clay modeling, papier-mâché

e) Potato and yam prints, stenciling

f) Drawing and painting

g) Weaving with raffia.

In art, the content of work progresses according to the child's development, this however allows for proper performance in the subject. The secondary schools curriculum is determined by the General Certificate Examination and the content becomes more intense, elements and principles of arts that is the visual vocabulary is being introduced, followed by art appreciation. Most of what is taught at this level begins to introduce the society and its essential features to the students. Art mirrors the society, so invariably the art work is a text. Students are introduced to skills in various areas of the Visual Arts: painting, ceramics, textiles, Graphic designs, and sculpture. Each of the units mentioned have different areas where students can be exposed to creative concepts which can be used for self development. Examples are: Tie and Dye, batik, embroidery, appliqué (both hand and machine) tailoring, printing, engraving, typography, photography illustration, book design, moulding, hand building, throwing, construction, tiling, carving, welding etc. (Bashen and Nyohom, 2012). From any of the areas abilities can develop from learning through good tutelage.

\section{Why Visual Arts is Necessary}

Training in the Visual Arts empowers students with skills and they develop constructive mental ability. Dashen and Nyohom, (2012). Are of the opinion that on the process of creation, certain useful qualities are acquired such as; observation, students develop the power to observe objects and to represent some on any suitable surface. Imagination is the aspect which reveals how the work of art is achieved. It is known that all works of invention are produced or created from imagination and thinking. That which comes out is from the abundance stored in the mind. Aesthetics is also created from the concept of beauty. It is the concept of appreciating art works; art encourages art appreciation as part of its training. In all lives endeavour, there is the desire for the pleasurable, the good and the beautiful. It is clear that the notion of beauty has diverse implications that exceed the physical appearance. The element of goodness therefore is a variance of that which is beautiful in many African cultures. There is hardly a distinction between the English words beautiful, good, nice, fine even enough.

Art in education portends the following specific social benefits:

i. Through art, pupils can develop their skill in the use of materials through experimentation, manipulation and practice.

ii. Art is a way to become a creative person in almost all fields of endeavour.

iii. Art is a way to become a flexible, confident person through the presentation of ideas in visual language.

iv. Art is the way to clarify and fix ideas in the mind through visual reiteration, strengthening what has been learnt about something.

v. Art finds practical use in other subjects; some subjects need illustrations and experiments. Good and accurate illustrations are helpful in explaining points, which may be difficult to explain in words. (Enamhe, 2001).

\section{Conclusion and Recommendations}

This paper concludes that if the Visual Arts is introduced in all levels of education, the youths will be self employed and also become employers of labour. It is therefore pertinent that the subject be introduced in the primary and secondary schools. The importance as it pertains to child development cannot be overlooked. The creative process begins from the scratch. Parents, teachers and educational planners could be well informed as stake holders. This understanding and knowledge will create awareness and delineate the impression that art is for failures and a dumping ground for the never do well.

Art clubs for children, teenagers and adults should be encouraged. Exciting programmes should be introduced. This is an excellent way to creating awareness about art. Suitable studios for visual arts should be built. Teachers who 
are not trained should not be allowed to teach art. The students should be exposed to all aspects of the Visual Arts, this will stimulate interest, especially when they see the different creations by other children.

\section{References}

Ajibade Babson, Enamhe Bojor, \& Oloidi Oluwole.( 2011) "Is Fine Art Inevetiable requisite for bachelor Degree in Visual Arts?: Notes from the Admission Policy of a Nigerian university" Mediterranean Journal of Social Sciences Vol. 2, No. 3. p. 203.

Ajibade, B. \& Lawson, I. (2003). The Limitations of Teaching and Learning Fine and Apllied Arts at the Tertiary level in Cross River State, Calabar Metropolis. Global Journal of Educational Research, 2(1\&2) 27-32.

Dashen Phoebe and Nyohom F. F. Wangkes,( 2012) "Reinvigorating Arts for Empowerment and Self-reliance in Nigeria" Knowledge Review, Muti-Disciplinary Journal Vol. 26, No: 2.

Echeta Chris,( 2011) "The Roles of Visual Arts in National Development". Journal of Educational Innovators Vol. 4, No:1 p

Enamhe Bojor,(2010.) "Sectoral Appraoch to Arts Administration: A study of Museums and monuments in Akwa Ibom and Cross Rivers States of Nigeria". An Unpublished Ph.D Thesis University of Calabar, Calabar.

Enamhe, Bojor \& Echeta, Chris. (2008) Art in Education: Meeting the Challenges" Journal of Educational Issues JEI Vol 4-p. 45.

Enamhe, Bojor "Barriers to Understanding Fine Arts, Journal of Education issues Vol. 3 November 2001 p. 154-161.

Jefferson, B. (1973) Teaching Art to Children. Boston: Studio Vista.

Keads, H.( 1975) Education through Art New York 1958.

National Association for Promoting Educational Innovations (NAPEIN)

Gardner, H. Art through the Ages, New York: Harcourt Brace Jovanovich.

National Association for the Advancement of Knowledge. University of Benin.

Brown I. N. Uzoagba,( 2002) Understanding Art in General Education. Africana Feb Publishers Limited, Nigeria.

Talabi, G.( 1979) Art Teaching in African Schools. Ibadan: Heiriemam.

Ugiomoh, F. (2012) Inaugural lecture Series No. 92. "African Art and Identity Blogging: A Historical Perspective. University of PortHarcourt, Nigeria. 